\title{
NOTES AND COMMENTS
}

\section{THE GENETICS OF DROSOPHILA MELANOGASTER COURTSHIP SONG-DIALLEL ANALYSIS}

\author{
D. E. COWLING \\ Dept. of Genetics, University of Sheffield*
}

\section{INTRODUCTION}

MALE Drosophila melanogaster produce a courtship song by vibrating their wings, in a specific code by which females identify conspecific males. It also stimulates the female to copulate (Bennet-Clark, Ewing and Manning, 1973). The sound is made up of sine song and pulse song. The time interval between pulses (the interpulse interval (ipi)) is important in discrimination between species. Different species produce different ipi's, but females only respond to the ipi of their own species (Bennet-Clark and Ewing, 1969).

The ipi's of a male vary in length, and the mean ipi's of different laboratory strains also differ. I have sought to establish whether females recognise a range of ipi values and if so, how wide this range is? If it were narrow then some males' ipi's would fall outside it, and would presumably show reduced fitness. The character would thus be subject to stabilising selection in which fitness is highest at a phenotypic optimum.

Alleles which always made for higher fitness would be favoured and might then be expected to evolve to a dominant state (Fisher, 1930), but with stabilising selection neither increaser nor decreaser alleles show an unconditional advantage. The commonest alleles should then show dominance (Fisher, op cit.). Thus characters under directional selection would be expected to evolve unidirectional dominance, whereas characters under stabilising selection would show weaker dominance of an ambidirectional kind (Mather, 1973). In addition some characters will make a larger contribution to fitness than others, and the "fitness" characters will have a larger ratio of dominance to additive variation than the so called "peripheral" characters (Robertson, 1955).

I report here on the genetical architecture of both ipi and sine song frequency (ssf). The function of the latter is not fully understood, but Schilcher (1976) reports that it may not be involved in species identification.

\section{Methods AND RESUlts}

The investigation was based on a simple diallel analysis (Hayman, 1954a and $b$ ). Four strains of $D$. melanogaster were used and the songs of at least 10 males were recorded and measured for each hybrid type and for the parents. Mean values were then used in the analysis.

Table 1 shows the diallel table of ipi's and table 2, the Hayman analysis of variance. Only item $a$ is significant; this indicates that genes controlling the

\footnotetext{
* Present address: Dept. of Genetics, University of Liverpool, Liverpool L69 3BX
} 
TABLE 1

Diallel table of interpulse interval (milliseconds) in male Drosophila melanogaster

Male parents

Female parents

$\begin{array}{lcccc} & \text { Novosibirsk } & \text { Congo } & \text { Canton } & \text { Oregon } \\ \text { Novosibirsk } & 31.83 & 28.53 & 31.22 & 32.12 \\ \text { Congo } & 28.92 & 26.86 & 28.57 & 28.93 \\ \text { Canton } & 30.64 & 29.65 & 32.26 & 30.37 \\ \text { Oregon } & 30.72 & 27.54 & 29.99 & 30.74\end{array}$

TABLE 2

Hayman's analysis of variance of the diallel table for interpulse interval

$\begin{array}{ccccc}\text { Item } & \text { Aspect of model tested } & \text { Degrees of freedom } & \text { Mean square } & F \\ a & D+H_{1}-H_{2}-F & 3 & 10 \cdot 76 & 29 \cdot 08^{*} \\ b & H_{2} & 6 & 0 \cdot 56 & 1.51 \\ b_{1} & \text { Directional dominance } & 1 & 1 \cdot 29 & 3 \cdot 49 \\ b_{2} & H_{1}-H_{2} & 3 & 0 \cdot 19 & 0 \cdot 51 \\ b_{3} & \text { Residual dominance } & 2 & 0.76 & 2 \cdot 05 \\ c & \text { Maternal effects } & 3 & 0.58 & 1.57 \\ d & \text { Other reciprocal effects } & 3 & 0.37 & \\ \text { Total } & & 15 & & \end{array}$

${ }^{*} p<0.05$

TABLE 3

Diallel table of sine sang frequency $(\mathrm{Hz})$ in male Drosophila melanogaster

\begin{tabular}{lcccc} 
Male parents & \multicolumn{4}{c}{ Female parents } \\
\cline { 2 - 5 } Novosibirsk & Congo & Canton & Oregon \\
Novosibirsk & 142.5 & $164 \cdot 0$ & $145 \cdot 0$ & 160.9 \\
Congo & 160.3 & 189.5 & 169.9 & 176.3 \\
Canton & 160.5 & 164.8 & 161.5 & 159.0 \\
Oregon & 158.9 & 170.7 & 158.5 & 162.3
\end{tabular}

TABLE 4

Hayman's analysis of variance of the sine song frequency diallel table

$\begin{array}{cccrc}\text { Item } & \text { Aspect of model tested } & \text { Degrees of freedom } & \text { Mean square } & \text { F } \\ a & D+H_{1}-H_{2}-F & 3 & 497 \cdot 2 & 12 \cdot 8^{*} \\ b & H_{2} & 6 & 26 \cdot 4 & 0 \cdot 7 \\ b_{1} & \text { Directional dominance } & 1 & 7 \cdot 2 & 0 \cdot 2 \\ b_{2} & H_{1}-H_{2} & 3 & 42 \cdot 6 & 1 \cdot 1 \\ b_{3} & \text { Residual dominance } & 2 & 11 \cdot 7 & 0 \cdot 3 \\ c & \text { Maternal effects } & 3 & 13 \cdot 7 & 0 \cdot 4 \\ d & \text { Other reciprocal effects } & 3 & 38 \cdot 9 & \\ \text { Total } & & 15 & \end{array}$

$* p<0.05$ 
ipi variation were largely additive and that there was no significant dominance. For ssf, the diallel table is shown in table 3 and the analysis of variance in table 4. Again dominance was not detected and only the additive component was significant.

\section{DisCUSSION}

The experiments indicate a genetical architecture for both interpulse interval and sine song frequency characterised by a high degree of additivity and little or no dominance variation. Dominance however is the "hallmark" of fitness characters, since the evolution of dominance ensures that the maximal number of genotypes express the favoured, optimal phenotype.

That ipi and ssf do not show dominance would suggest that their observed variation is not critical for the male's Darwinian fitness. It is therefore likely that a range of values are equally acceptable to female Drosophila and that only widely deviant songs are maladaptive. Evidence from song simulation experiments suggests that this is indeed the case. Females were courted by wingless males in the presence of an artificial song whose ipi could be varied, and it was discovered that the tolerated range of values was high. Mating was about equally successful between ipi's of 25 and $40 \mathrm{~ms}$. Success only fell with ipi's outside this range, but then the reduction was large.

Acknowledgements.-I thank Drs B. Burnet, J. A. Bishop and M. J. Kearsey for advice. This research was supported by the MRC.

\section{REFERENCES}

BENNET-CLARK, H. C., AND EWING, A. W. 1969. Pulse interval as a critical parameter in the courtship song of Drosophila melanogaster. Anim. Behav., 17, 755-759.

BENNET-CLARK, H. C., EWING, A. W., AND MANNING, A. 1973. The persistence of courtship stimulation in Drosophila melanogaster. Behav. Biol., 8, 763-769.

FISHER, R. A. 1930. The Genetical Theory of Natural Selection. Clarendon Press, Oxford. HAYMAN, B. I. 1954 a. The analysis of variance of diallel tables. Biometrics, 10, 235-244. HAYMAN, B. I. 1954b. The theory and analysis of diallel crosses. Genetics, 39, 789-809. MATHER, K. 1973. The Genetical Structure of Populations. Chapman and Hall, London. ROBERTSON, A. 1955. Seleçtion in animals: synthesis. Cold Spring Harb. Symp. Quant. Biol., 20, 225-227.

SCHILCHER, F. VON. 1976. The function of pulse song and sine song in the courtship of Drosophila melanogaster. Anim. Behav., 24, 622-625. 